\title{
AS MARCAS ESCRITAS QUE ORIENTAM A PROSÓDIA NO TEXTO PUBLICITÁRIO
}

\section{Maurini de Souza Alves Pereira ${ }^{1}$}

\section{Resumo}

A publicidade impressa se mostra eficiente para demonstrar as funções entonacionais apontadas por Couper-Kuhlen (1986), responsáveis pelo contraste de significados em orações ambíguas ou utilizadas em diferentes situações. O texto publicitário escrito busca atingir ao máximo seu leitor, que, no Brasil, é muito mais propenso à imagem e som (televisão e rádio) do que à literatura. Utilizando marcas visuais, o anúncio sugere a entonação e impõe o ritmo designado pelo seu autor na busca de um texto eficaz, isto é, capaz de vender o produto que divulga.

Palavras-chave: Publicidade, prosódia, entonação, comunicação escrita e oral.

\begin{abstract}
The printed advertising is efficient to demonstrate the intonational functions pointed by Couper-Kuhlen (1986), responsible for the contrast of meanings in ambiguous phrases or used in different situations. The written advertising searches to reach to its reader, who, in Brazil, is much more inclined to the image and sound (television and radio) than to literature. Using visual marks, the advertisement suggests the intonation and imposes the rhythm assigned by its author in the search of an efficient text, that is, a text capable to sell the product that it shows.
\end{abstract}

Keywords: Advertising, prosody, intonation, written and verbal communication.

\section{Introdução}

Comentando um trecho da obra de Proust (Du coté de chez Swann), Barbosa (1999) aponta os literatos como inigualáveis para trabalharem com o ritmo da língua por meio de textos escritos, assinalando os sinais de pontuação e o jogo com o comprimento e estrutura das palavras como responsáveis pela determinação dessa ritmicidade, ligada aos parâmetros visuais do texto escrito: “Como não perceber nesse parágrafo proustiano antológico a descrição quase tangível de uma chuva repentina? O espaçamento entre as vírgulas guia a leitura, e as amplas proporções do início do texto vão aos poucos sendo substituídas por outras, mais curtas, formadas por palavras que caracterizam a chuva" (BARBOSA, 1999, p. 21-22).

Além da literatura, porém, outro gênero se destaca pela liberdade nos padrões formais e pode ser utilizado para exemplificar essa relação entre escrita e prosódia: o texto publicitário. Em termos de Brasil, setenta por cento da publicidade feita neste país utiliza-se da "língua oral e a imagem" (CARVALHO, 2003, p. 27) por se destinar à televisão; os outros trinta por cento se divIdem entre rádio que, apesar de possuir uma audiência representativa no

\footnotetext{
${ }^{1}$ É graduada em Jornalismo e Letras e mestre em Letras pela Universidade Federal do Paraná (UFPR). Faz doutorado em Letras na mesma instituição. Professora do Departamento de Comunicação e Expressão da Universidade Tecnológica Federal do Paraná (UTFPR).
} 
cenário nacional ${ }^{2}$, produz in loco seus anúncios e trabalha maciçamente com testemunhais ${ }^{3}$, não computados nesses dados de agências de propaganda, e um número significativamente menor para impressos. Estatística explicada pelo fato de que o Brasil está entre as nações que mais assiste à televisão no mundo e, em contrapartida, tem um destaque negativo para a leitura ${ }^{4}$.

Dentro dessa realidade e com o desafio de criar um texto eficiente dentro dessa minoria impressa, o publicitário tem se dedicado em tornar o texto escrito atraente a esse público que garante a expressiva audiência de televisão e rádio, e que em uma primeira instância, não está habituado à leitura, mas que lerá um texto com "boa argumentação", "divertido" e que emocione (LINDENBERG, 2002).

Alguns princípios são levados em conta para essa conquista, como "não exigir do consumidor esforço para que a mensagem seja compreendida" (SIEVERT, 2001, p. 25), "facilitar a vida do leitor" (MAGGY, 1995, p.122), fazer o texto agir tal qual a "mãe que conta histórias para fazer com que a criança 'engula' passiva e imperceptivelmente a comida apresentada e de que nem sempre necessita” (CAMPOS, 1987, p.28), "preparar o material com o máximo de clareza [...] deve ser entendido imediatamente" (OGILVY, 1976, p. 64-104), mas não se conformar com a mediocridade (MARTINS, 1997, p. 70), ser inteligente (SIEVERT, 2000 , p. 31) e ter em mente que "somos expostos diariamente a umas 2000 mensagens publicitárias. Então temos que atravessar essa confusão da mídia, sair da mesmice" (MAGGY,1995, p. 120).

As informações acima demonstram a necessidade de atrair o receptor, chamando atenção por meio da mensagem, e conduzi-lo, para que ela tenha um efeito rápido e não questionador.

Tais preocupações levam o autor a investir em marcas no texto que orientem sua entonação, aproximando o anúncio impresso do produzido para a mídia eletrônica. Este trabalho procura demonstrar, baseado nos estudos sobre prosódia, alguns momentos em que o texto publicitário impresso - em revistas, jornais ou outdoors - procurou orientar a entonação por meio de marcas, que vão desde pontuação até estrutura de palavras, tal como demonstrou Barbosa com referência à ritmicidade imposta por Proust em sua obra.

\footnotetext{
2 “A rádio é a principal fonte de notícias para os adultos durante o período da manhã: $38 \%$ contra 37 da TV e 20 dos jornais" (BARTLETT, apud MEDITSCH, E. A rádio na era da informação. Teoria e técnica do novo radiojornalismo. Florianópolis: EdUFSC/Insular, 2001. p. 27).

${ }^{3}$ Testemunhal em rádio é o anúncio lido ou falado diretamente pelo locutor, publicidade não gravada.

${ }^{4}$ No seminário Mídia 2000, em Curitiba (Centro de Convenções do Parque Barigui, 2000), a Rede Globo de Televisão foi apontada como a emissora televisiva de maior audiência no mundo. Com relação à leitura, a situação é diferente: "Segundo a pesquisa Retrato da Leitura no Brasil, da CBL, 61\% dos brasileiros adultos alfabetizados têm muito pouco ou nenhum contato com os livros.” (JORGE, $C$. http://www.radiobras.gov.br/materia.phtml?materia=187985\&q=1\&editoria 02/06/2004).
} 
Para isso, haverá um breve levantamento de algumas características dos textos publicitários, também uma exposição sobre alguns pontos determinantes na fonologia prosódica e, finalmente, a apresentação de algumas peças publicitárias que utilizam técnicas para, através de marcas visuais, gerarem efeitos prosódicos.

\section{Texto publicitário}

Vestergaard e Schrodder (2000) classificam publicidade ("propaganda comercial”) 5 em três categorias: institucional ou de prestígio, responsáveis por divulgar a imagem da empresa; industrial, em que divulga produtos para outras empresas, enfatizando mais "as informações concretas" do que os "elementos de persuasão" (p. 2); e a do consumidor, com foco individual. Os anúncios apresentados neste trabalho são voltados ao consumidor, pois os textos publicitários apontados, que trazem marcas para dirigirem a leitura, têm um foco emotivo, e não racional; apesar deste ser utilizado também para anúncios para o consumidor, aquele é praticamente exclusividade dessa categoria.

O texto publicitário deve levar em conta o perfil do consumidor, analisando fatores como idade, sexo, classe social do receptor ou público-alvo, buscando, por meio de pesquisas, o possível comprador do produto anunciado. Martins (1997) acrescenta a essa lista os resultados de um planejamento que leve em conta os concorrentes, pontos de vendas e o diferencial do produto, que restringirá ainda mais um enfoque.

Sievert (2001) desenvolveu um estudo, tomando como base os arquétipos de Jung, em que apresenta cada modelo de consumidor dentro de padrões associados aos deuses gregos. Por exemplo, o arquétipo Zeus refere-se ao homem com características de chefia, organizador, conservador e que se preocupa com a imagem; para ele, comprador potencial de carros importados, notebooks e ternos, é preciso investir em um texto com foco racional, mas que valorize a posição social. Afrodite, por sua vez, é o modelo da mulher sensual, que se preocupa com a beleza do seu corpo, no que é diferente de Ártemis, ligado à natureza, que se refere à mulher preocupada com a saúde de seu corpo. Para a primeira, perfumes e jóias em um texto com palavras românticas, sensoriais, maliciosas, ambíguas; para a segunda, cereais e conforto integrando um anúncio com ênfase no meio ambiente. Dos anúncios apresentados na última sessão deste trabalho, os dois referentes à função indicadora seriam voltados a Zeus e Afrodite, respectivamente; já o que demonstra a função textual ou discursiva é aplicável a Ártemis.

\footnotetext{
${ }^{5}$ Apesar de possuírem pontos diversos (vide BIGAL, 1993:21-23), tanto o termo publicidade quanto propaganda são utilizados para designar o anúncio comercial. Portanto, os dois aparecerão como sinônimos neste artigo. Vestergaard e Schroder distinguem a propaganda sem fins comerciais, a que chamam de não-comercial, e a publicidade, que denominam "propaganda comercial".
} 
E assim Hera, Perséfone, Atena, Deméter, Ares, Apolo, Hades, Hermes, Hefestos e Eros compõem os arquétipos femininos e masculinos que, ao lado dos anúncios voltados ao que a autora chama de "andróginos", procuram cercar todos os tipos de comportamentos dos potenciais consumidores dos produtos para os quais o anúncio é produzido.

Menna Barreto (1982), para quem criatividade é sinônimo de "solução de problemas" (BARRETO, 1982, p.69) orienta inclusive os passos a se seguirem para uma boa criação, e eles começam com pesquisa envolvendo todos os elementos apresentados acima, seguida pelo que o autor chama de "incubação", que é um tempo sem trabalhar com o assunto, iluminação, momento em que a idéia deverá surgir, e por fim, a verificação, que é a adequação entre a idéia e o contexto.

Portanto a criatividade no texto publicitário é conjugada a um fator maior: eficácia, medida pela capacidade de venda, pois "o papel da propaganda é vender" e "o papel da criação é aumentar a eficácia" (MAGGY, 1995, p. 120). Esse atributo é vislumbrado nos momentos em que o texto carrega marcas que orientam a leitura, aproveitando, assim, características prosódicas para alcançar seu fim.

\section{Prosódia}

Estudos prosódicos tratam desse tema enfocando dois aspectos: o de produção e o de percepção. O primeiro se sustenta em três elementos, mais ou menos perceptíveis aos ouvidos do receptor, que são apontados como duração, intensidade ou sonoridade e frequiência fundamental (SCARPA, 1999, p.22) ou pitch (CRUTTENDEN, 1997: p.3) ou qualidade vocálica (MASSINI-CAGLIARI, 1992, p. 38). Cruttenden (1997) aponta outros parâmetros, como "pausa" ou "tempo" como também atuantes, mas não prioritários.

A duração, mais facilmente identificável, é relacionada a tempo de produção da unidade estabelecida - normalmente uma sílaba. É o principal "correlato físico do acento no português do Brasil” (MASSINI-CAGLIARI, 1992, p. 18).

A intensidade ou sonoridade (loudness) é apresentada por Massini-Cagliari (1992) como o segundo "correlato físico do acento" (p.21) do português brasileiro, conjugado à duração. ${ }^{6} \mathrm{O}$ acento no português é chamado de "de intensidade" (BORBA, 1967, p. 175), diferindo de línguas como, por exemplo, a chinesa, considerada uma língua "de ritmo tonal" (Idem). A

\footnotetext{
${ }^{6}$ Nos dados levantados, Massini-Cagliari (1992) chegou às seguintes conclusões: 29\% - acento caracterizado só pela duração. $10 \%$ - acento caracterizado só pela intensidade. $61 \%$ - pelos dois (p.23).
} 
sonoridade é percebida como a "força respiratória utilizada pelo falante" (CRUTTENDEN, 1997, p.2), mas é a que menos atua na percepção da sílaba acentuada (Idem).

Sobre pitch ou freqüência fundamental ou qualidade vocálica, Cruttenden (1997) apresenta uma explicação que elucida a inter-relação entre esses termos diferentes que procuram explorar a mesma característica. Segundo ele, o pitch é o traço prosódico mais envolvido na entonação, relacionado à vibração das cordas vocais, que, por sua vez, é controlada pela frequiência fundamental, definida pelo autor como o número de repetições do formato de onda (waveform) dentro de um segundo, decorrente da vibração das cordas vocais para produzir voz. O número de vezes em que as cordas abrem e fecham completamente em um segundo é diretamente relacionada à frequiência de um formato de onda (p. 3$)^{8}$.

Nos homens, a variação da freqüência fundamental é entre 60 e $240 \mathrm{~Hz}$, com uma média de 120 Hz. Nas mulheres, entre 180 e 400hz, e a média, 220 Hz. Nas crianças, a média é de 265 $\mathrm{Hz}$.

Esses traços atuam, no português, criando uma relação de proeminência (às vezes chamada de stress ou acento, dependendo dos autores ${ }^{9}$ ) entre as sílabas. As seqüências entre sílabas proeminentes, consideradas tônicas, e não proeminentes, átonas, são as bases estruturais dos estudos prosódicos. A relação acentual não é desvinculada da estrutura silábica da frase, "um peso silábico é um fator importante para regras de acento. Uma sílaba longa tem o Núcleo ramificado, indicando uma sílaba pesada" (MASSINI-CAGLIARI, 1999, p.89). Por exemplo, uma palavra como im-por-ta, nunca seria proparoxítona no português, porque a penúltima sílaba é pesada, isto é, é composta pela consoante Onset, a primeira parte da sílaba ( $p$ ), a vogal Núcleo $(o)$ e a consoante Coda $(r)$. Moraes (1988) afirma ser esse um vestígio do latim, no qual as palavras só poderiam ser proparoxítonas se a penúltima sílaba fosse leve.

Outra relação é quanto à duração da sílaba, "inversamente proporcional ao número de sílabas em uma palavra ${ }^{10 "}$ (MORAES, 1988). Outros pontos que interferem na duração são características das vogais e consoantes; por exemplo, vogais mais abertas são mais longas que mais fechadas, e nasais, mais longas que não nasais (MORAES, 1999, p. 79-80), e consoantes

\footnotetext{
${ }^{7}$ Do original "breath-force which a speaker uses" (trad. minha).

${ }^{8}$ Do original "number of repetitions of the regular waveform within one second, such a regular waveform being typically produced when the vocal cords vibrate for voicing. So the number of times that the vocal cords completely open and close in one second is directly related to de frequency of the waveform." (trad. minha).

9 "The term ACCENT will be limited to prominences where pitch is involved (hence it is equivalent to PITCH ACCENT) 'Stress' is therefore being used in the more general, less specified, way" (CRUTTENDEN, 1997: p. 13).

${ }^{10}$ Do original "Syllabic duration is inversely proportional to the number of syllables in a word." (trad. minha).
} 
sonoras abaixam a freqüência fundamental das vogais abertas e surdas elevam (MASSINICAGLIARI, 1999, p.39).

Esse ponto remete ao estudo de Massini-Cagliari (1999), sobre acento e ritmo, em que apresenta a sílaba, e não a vogal, como unidade de manifestação do acento. Ela mediu separadamente vogais de consoantes para chegar a essa conclusão e observou que, apesar da dominância das primeiras, as segundas também interferem nesse sentido. A forma com que se produz a proeminência das sílabas dentro do enunciado, e não da palavra, é responsável pelo ritmo da fala. Para a autora, ritmo é "a maneira que a linguagem tem para organizar no tempo o que deve ser dito" (p.11). Essa ligação ritmo-tempo também é observada em Barbosa (1999), para quem ritmo é a "variação da duração percebida a longo termo" (p.23). O acento frasal nem sempre coincide com o da palavra, dentro do enunciado; quando, por exemplo, duas sílabas tônicas se encontrariam em uma frase, uma delas normalmente perde sua tonicidade, seguindo ao chamado "princípio da alternância rítmica" ((MASSINI-CAGLIARI, 1999, p.194), em que, no enunciado, as sílabas fortes e fracas se alternam. Por exemplo, nas palavras laVOU e fiCOU, não há dúvidas de que as sílabas mais fortes são as últimas; no entanto, no anúncio (anexo) “ALva LAvou ALvo Ficou”, o peso das sílabas é deslocado em favor ao princípio de alternância rítmica.

Outra abordagem ao estudo prosódico é estudada por Couper-Kuhlen (1986), que associa entonação a contraste de significados. Ele apresenta entonações diferentes em ambientes ou significados diferentes no inglês, mas que podem ser aplicados também ao português. As funções apontadas são informacional, gramatical, elocucional, atitudinal,textual ou discursiva e indicadora. ${ }^{11}$

$\mathrm{Na}$ função informacional, apresenta a entonação contribuindo para o "significado da informação relatada ${ }^{12 "}$ (COUPER-KUHLEN, 1986, p. 111). O autor se baseia em Halliday (1967) para suas afirmações de que um texto é formado por unidades de informação que nem sempre coincIdem com unidades gramaticais, mas sempre com as entonacionais. No exemplo apresentado, “João viu a peça ontem” (COUPER-KUHLEN, 1986, p. 122), ele demonstra que a estrutura do constituinte não determina o número de informações; neste caso, há um constituinte (“João viu a peça ontem”) e três informações (João, a peça e ontem).

O que demonstrará quais dessas informações são novas e quais são conhecidas é a entonação. Para uma questão em que a informação nova seja João, respondendo à pergunta

\footnotetext{
${ }^{11}$ No original "Informational", "Grammatical”, "Illocutionary", “Attitudinal”, "Textual/discourse" e "Indexical”. (trad. minha).

${ }^{12}$ No original "to information-related meaning" (trad. minha).
} 
- Quem viu a peça ontem? - Haverá um foco na fala para essa palavra: JOÃO viu a peça ontem; para a resposta à pergunta - O que João viu ontem? - João viu a PEÇA ontem; e para - Quando João viu a peça? - João viu a peça ONTEM. O autor explica que uma informação conhecida tende a ser pronunciada com pitch mais baixo e a nova, com um pitch mais alto. Também há diferença na configuração do pitch no nível informacional em casos de informação contrastante. Por exemplo, se houver uma pergunta como João viu o futebol ontem?, a resposta será Não, ele viu A PEÇA ontem. Couper-Kuhlen resume essa função da seguinte maneira:

Se formos listar as funções das quais entonação preenche a estrutura de informação, a lista incluiria o seguinte: (1) unidades tonais realizam unidades de informação, (2) os núcleos sinalizam a presença de focos informativos; (3) pitch alto $\mathrm{x}$ baixo marcam informação nova vs conhecida; (...) (4) a posição do núcleo determina foco marcado vs não marcado ${ }^{13}$. (IDEM, p. 128)

No texto publicitário, a marca, informação nova, deve preponderar sobre as outras.

$\mathrm{Na}$ função gramatical, o constituinte sintático pode corresponder ao prosódico, nesse caso, a “entonação (isto é, posição do núcleo) tem função sintática ${ }^{14 "}$ (IDEM, p.112) e serve para dissolver ambigüidade. A autora destaca que, desde o século XVI, há estudos que associam entonação e gramática, numa visão de interdependência que persiste até hoje (IDEM, p.139), mas há argumentos contra essa interdependência, como o grande número de exceções nos casos. Algumas co-ocorrências, porém, deixam claros os momentos em que a entonação exerce uma função gramatical. Em uma oração como "Posso oferecer-lhe chá ou café?" (IDEM, p.146), o que marca a diferença entre uma questão com resposta entre uma das alternativas ou afirmativanegativa é a entonação. Por exemplo, a resposta para Posso oferecer-lhe CHÁ ou CAFÉ? seria excludente (chá ou café), mas para POSSO oferecer-lhe chá ou café? seria sim ou não. A diferença entre uma oração explicativa e uma restritiva também exemplifica essa função que, no texto publicitário, tende a conduzir o leitor a respostas excludentes e explicativas, já que não pretende salientar concorrência.

A função elocucional "sinaliza a força intencional de um enunciado em dado contexto"15 (IDEM, p.112). A oração "Por que você não vai para a Califórnia?"(IDEM) pode esperar a resposta Porque não quero ou Boa idéia, irei, de acordo com a situação em que o

\footnotetext{
${ }^{13}$ Do original "If we were to list the functions which intonations is claimed to fulfill with respect to information structure, the list would include the following: (1) tone-units realize units of information; (2) the nucleus signals the presence of information focus; (3) high vs. low pitch marks new vs given information; (...) (4) the position of the nucleus realizes unmarked vs. marked focus." (trad. minha).

${ }^{14}$ Do original "intonation - i.e. position of the nucleus - has syntactic function." (trad. minha).

${ }^{15}$ Do original "it signals the intentional force of na utterance in a given context". (trad. minha).
} 
emissor e o receptor se encontram. Pode ser uma sugestão ou um questionamento À diferença entonacional entre essas duas questões o autor denomina elocucional. Na publicidade, toda a pergunta é sugestiva e a disposição textual busca esclarecer essa função.

A função atitudinal da entonação é responsável por mostrar os sentimentos do falante. Uma pessoa pode falar "Isto é ótimo" (IDEM) porque está feliz com algo, mas pode dizer a mesma coisa, em tom irônico ou triste. Na publicidade, alguns textos são estruturados de formas a sugerirem a alegria do leitor.

A função textual ou discursiva é observada quando duas orações são ou não unidas na fala. Ela se refere à coesão textual; por exemplo, um texto é subdividido em parágrafos, e é possível haver variação dentro desta subdivisão, ampliando-a ou reduzindo-a, por meio da entonação. Muitos anúncios, por exemplo, utilizam ponto final onde, a princípio, não seria o limite da oração. É um exemplo de função textual.

E, por fim, apresenta uma das funções da entonação mais explorada pela publicidade: a indicadora. Essa função demonstra as diferenças sociais ou individuais da fala, como as que indicam sexo, idade, classe ou região. Está intrinsecamente ligada aos estudos que abordam o perfil do consumidor, e o texto que se relaciona a essa função pretende levar o leitor a uma empatia com o emissor ou reconhecimento de pessoas com quem convive no dia-a-dia. Por exemplo, no anúncio das Tintas Coral, de 1969, (anexo) “Como é, patrão, vamos dar uma polidinha no carango?" O consumidor é orientado a reproduzir a entonação de um menino que cuida de carros na rua. É impensável, em tal texto, que a leitura seja feita pausadamente, como um senhor de idade avançada ou mesmo uma mulher. Um texto como esse exemplifica a função entonacional indicadora de classe social, idade e sexo.

Esse levantamento de fatores prosódicos envolvidos nas enunciações é fundamental para uma demonstração de textos publicitários que se aliam às funções de entonação para criarem efeitos no leitor, que vão desde a instituição de uma familiaridade maior com os textos até a intenção de aproximar o texto escrito a um consumidor que prefere sons e imagens.

\section{O texto publicitário explorando fatores de entonação}

Nesta seção serão apresentados alguns textos que ilustrarão a proposta deste trabalho. Foram escolhidos anúncios atuais e antigos, para demonstrar que essa tendência à orientação entonacional não é atual, mas faz parte do texto publicitário há muito tempo. Por exemplo, quando o anúncio do refrigerante $\mathrm{H} 2 \mathrm{OH}$ ! (anexo) se utiliza dessa grafia para que o leitor reproduza a fala que expressa a sensação de frescor, espelha o mecanismo utilizado 
pelo Karmann Ghia TC (anexo) em 1971, que traz o título “Ohhh”, da expressão de admiração - aumento na duração e elevação do pitch de $O$.

Essa articulação em fatores prosódicos pode ser incluída na busca por assemelhar a escrita à fala na propaganda, ciente de que "A palavra falada envolve todos os sentidos intensamente" (MCLUHAN, 1969: p. 95). McLuhan, para quem "o meio é a mensagem" (IDEM, p. 21), apresenta a escrita como conteúdo da imprensa e a fala como conteúdo da escrita, mas quando se pergunta quanto ao conteúdo da fala, amplia a resposta para "processo de pensamento, real, não verbal em si mesmo" (IDEM, p.22). Ele considera esclarecedor confrontar a fala com a escrita que a reproduz, exemplificando com a palavra "noite", que pode ser escrita de poucas maneiras, mas era falada pelos atores de Stanislavsky de mais de cinquienta formas diferentes.

Além disso, ao falar, tendemos a reagir a cada situação, seguindo o tom e o gesto até de nosso próprio ato de falar. Já o escrever tende a ser uma espécie de ação separada e especializada, sem muita oportunidade e apelo para a reação. $\mathrm{O}$ homem ou a sociedade letrada desenvolve uma enorme força de atenção em qualquer coisa, com um considerável distanciamento em relação ao envolvimento sentimental e emocional experimentado por um homem ou uma sociedade não letrada. (MCLUHAN, 1969:p. 97)

Como a publicidade busca sempre uma reação - a compra - e para isso, procura tal “envolvimento sentimental e emocional”, investir em marcas na escrita que a aproximem da diversidade nas formas de falar, numa sugestão de entonação, é coerente com suas propostas e sua forma de agir.

Vestergaard e Schroder (2000) também retomam os estudos de Halliday (1967) para apresentarem o "acento nuclear (...) última sílaba tônica do grupo" (VESTERGAARD E SCHRODER, 2000: p.20) como instrumento para a explicitação do foco em uma unidade informacional. No título do anúncio do sabonete Lever (anexo), veiculado entre os anos quarenta e cinqüenta do século passado, os primeiro foco é sublinhado e, no segundo, a palavra aparece entre aspas, procurando explicitar no texto a função informacional da entoação: "Para ele Você é tão linda quanto uma "estrela" de cinema". No texto em destaque, ao lado da foto do produto, as aspas são mantidas: "Usado por 9 entre 10 "estrelas" do cinema". Nos dois focos, a "última sílaba tônica do grupo" - e, em ele, e ter, em estrelas - é enfatizada, exemplificando a ligação entre a publicidade escrita e as funções entonacionais. Outra forma utilizada para indicar foco na publicidade impressa é a alteração na fonte ou no tamanho da palavra a ser destacada, como no anúncio da Revista Gol(SP, fev/2007: p.51): "Localização que é um Show". 
A revista PCGamer regeu uma estratégia de marketing para o lançamento do videogame PlayStation 3 sob o título "Você quer comprar um PS3 ou ganhar um PC de graça?"16. Nesse caso, o apelo entonacional está na semântica dos verbos apresentados - o peso de ganhar é muito maior do que de comprar, o que esclarece que essa co-ocorrência é excludente, não aceitando como resposta um sim, mas exigindo que se escolha um dos elementos. Outro exemplo de anúncio que se encaixa à função gramatical é o das baterias Saturnia, de 1971 (anexo), com o texto "O VW TL TAMBÉM USA BATERIA DE QUALIDADE”, em que o também, além de sublinhado, é grafado em amarelo, num conjunto escrito em preto. Haveria duas significações propostas pelo enunciado: vários carros, inclusive o $T L$, utilizam bateria de qualidade, restritiva, ou o $V W$, além de usar outras peças de qualidade, utiliza a bateria, explicativa. Foi apontado acima que, nesses casos, a tendência da publicidade é gerar uma explicativa, e é o que seria entendido, automaticamente, se não houvesse o destaque para o também, pois o destaque seria para o carro. Nesse caso, porém, como houve parceria entre empresas (Volkswagen e Saturnia), e o foco principal é a bateria, a marcação do também indica que o enunciado é restritivo.

"Se tiver que levar um grupo de amigos, você dá uma desculpa, confessa que não cabe em seu carro... ou você já tem um Belcar?” é o anúncio (anexo), de 1966, da empresa de carros $D K W$.

Cruttenden (1997) não acha que pausas existam somente para a respiração, pois se faz pausa em menor tempo do que se respira; "nós pausamos por outras razões e aproveitamos a oportunidade para respirar" (p.30). Ele aponta três situações no enunciado para pausa: 1] Relacionada ao limite do constituinte maior; 2] Antes de palavras de conteúdo lexical consistente - antes do limite do menor constituinte; 3] após primeira palavra do grupo entonacional. E explica que a primeira indica "o limite de um grupo entonacional" (p. 31), a

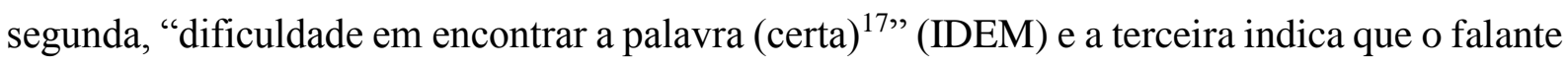
está planejando o que falar. As pausas dois e três, segundo o autor, são mais comuns nas falas não decorrentes de escrita do que nas falas preparadas ou provenientes de leitura.

Nesse caso, a pausa sugerida após a palavra carro vem de encontro à segunda situação apontada por Cruttenden; ele separa o menor constituinte, que por sua vez é portador do conteúdo principal do enunciado, com a função, neste caso, bem específica, que é a de sugestão. Como um conselho de quem possui "dificuldade em encontrar a palavra certa", por esta representar a solução para as questões propostas até então. Por conseguinte, a entonação dessa

\footnotetext{
${ }^{16}$ Apud http://www.forumpcs.com.br/noticia.php?b=190673.

${ }^{17}$ Do original "indicating an intonation-group boundary" e "a word-finding difficulty".
} 
frase demonstra que ela não é interrogativa, o emissor não tem curiosidade em saber em qual das opções se encontra o receptor, mas que sugere uma atitude, num exemplo da função elocucional apresentada por Couper-Kuhlen.

Exprimir sentimentos através da entonação é uma função atitudinal. Oliviero Toscani (2003), ao criticar a alienação da publicidade quanto ao mundo moderno, condenou o fato de que esse gênero ilude a população mostrando um mundo que não existe, repleto apenas de alegria, felicidade e satisfação. "Sobre este planeta extraordinário, a vida é bela" (TOSCANI, 2003, p. 16). Por conseguinte, os sentimentos nos quais as marcas impressas investirão serão sempre desse tipo. A empresa Sofá e companhia possui um anúncio que ilustra tal função: "É incrível o que ela pode fazer por você" (Revista Gol, fev/2007: p.13). O destaque para a palavra incrível sugere uma leitura em que se observa a elevação na intensidade da sílaba tônica (cri), com um consequiente declínio na última sílaba (vel). Essa é a tendência de fala de alguém bem-disposto, alegre e admirado, que combina com o padrão de comportamento que a publicidade quer enfocar.

"Costuma-se dizer que o texto de propaganda tende a seccionar as frases, usando pontos finais onde a prosa comum empregaria vírgulas ou nenhuma pontuação" (VESTERGAARD e SCHRODER, 2000, p.21) Essa característica está intrinsecamente ligada à tendência do texto publicitário em utilizar a função textual ou discursiva da entonação proposta por CouperKuhlen. No anúncio que ocupou duas páginas do jornal Folha de São Paulo sobre um condomínio na capital paulista, a primeira delas era preenchida pelo seguinte texto:

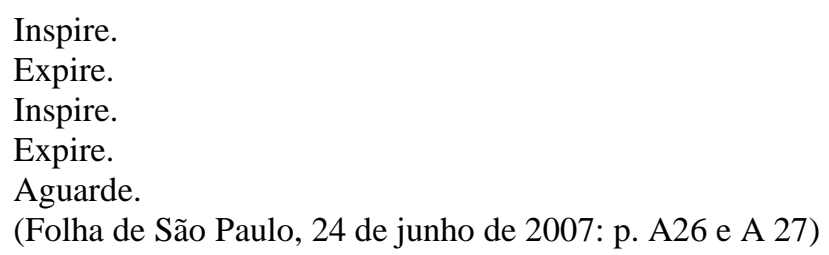

Conduzindo, em cada linha, a leitura do texto, sem nenhuma marca de ligação. Somente o ponto final separando cada verbo em uma frase isolada da outra. Vestergaard e Schrodder (2000) atribuem a esse uso a intenção de aumentar os elementos focais do texto, valorizando cada palavra. Neste caso, pode-se pensar que a repetição dos verbos, aliada à pontuação, tenta reproduzir o ritmo da respiração.

A função indicadora da entonação atua no texto publicitário como estrutura de plausibilidade à visão de Vestergaard e Schrodder (2000) quanto ao papel ideológico da propaganda. Segundo eles, a publicidade recomenda “como incontestável uma certa norma de 
comportamento" (p. 159) e reforça "as tendências que procuram tornar estática a sociedade (...) nos princípios básicos da ordem social, quer no nível macro ('democracia’), quer no nível micro (papel dos sexos)".

Por exemplo, no anúncio da Chrysler do Brasil S.A. (anexo), de 1969, o título é “Querido, pergunte à Chrysler quem criou o interior do Esplanada. Pretendo redecorar nossa casa.", sugerindo a voz de uma mulher, adulta e que domina a língua padrão. Além disso, a escolha da palavra redecorar orienta para uma pessoa requintada, de classe social alta, impondo um ritmo mais lento à leitura. Assim, o texto dirige também esse parâmetro, mostrando esse perfil como "norma de comportamento", e não exceção, como é o caso no contexto do país. Além disso, o texto reproduz a "ordem social" em que o homem compra o carro e a mulher decora a casa.

Outro exemplo desta função é o anúncio de AeroWillys (anexo), 1961, com os seguintes dizeres: "Noite de elegância... ambientes de bom gosto. E seu Aero-Willys - distinto, sóbrio, de linhas clássicas - acompanhando o sucesso de suas reuniões sociais”, em que a pontuação marca uma fala pausada, característica imposta pela publicidade como indicadora de classe social elevada.

\section{Conclusão}

O texto publicitário é exemplo, na sociedade moderna, de criação com liberdade de forma. Esse fator se alia ao fato de que se cria, no Brasil, muito mais propaganda com imagem e som do que para impressos, e que a população prefere aqueles a estes, para determinar um texto impresso que busque romper as barreiras do papel em que se encontra e ganhar vozes. Para isso, investe em marcas, que podem ser sinais de pontuação, mudança de fonte, tamanho, cor e estilo das letras, estrutura de frases e palavras e léxico. O objetivo é conduzir a entonação.

Por meio do estudo feito por Couper-Kuhlen (1986) a respeito das funções da entonação que definem contrastes de significados e com base em estudos que apontam os parâmetros para se avaliar a prosódia em um texto, foi possível criar uma analogia, com exemplos de textos de diferentes épocas do século passado, entre essa condução na entonação no universo publicitário e a teoria prosódica.

Assim, a publicidade se apresenta como um material farto e eficaz para esse estudo, demonstrando a aplicação dos estudos lingüísticos na esfera ideológico-social. 


\section{Referências}

BARBOSA, P. A. "Revelar a estrutura rítmica de uma língua construindo máquinas falantes pela integração de ciência e tecnologia de fala". in SCARPA, E.M. (Org) Estudos de prosódia. Campinas: Unicamp, 1999.

BARRETO, Roberto Mena. Criatividade em Propaganda. São Paulo: Summus, 1982.

BIGAL, S. Afinal, o que é criação publicitária? Ou (O estético na publicidade). São Paulo: Razão Social, 1993.

BORBA, Francisco da Silva. Introdução aos estudos lingüísticos. São Paulo: Nacional, 1967

CAMPOS, M. H. R.. O canto da sereia. Uma análise do discurso publicitário. Belo Horizonte: UFMG;PROED, 1987.

CARVALHO, N. Publicidade: A linguagem da sedução. São Paulo: Ática, 2003

COUPER-KUHLEN,E. An introduction to English prosody .London: Edward Arnold, 1986.

CRUTTENDEN, Allan. Intonation .Cambridge (UK): University Press, 1997.

Folha de São Paulo. São Paulo: 24 de junho de 2007.

LINDENBERG, R. Tem gente achando que você é analfabeto, e você nem desconfia. Wbrasil. In Jornal Valor Econômico, Rio de Janeiro: 13/08/2001.

MAGGY et. al. Tudo o que você queria saber sobre propaganda e ninguém teve paciência para explicar. São Paulo: Atlas, 1995.

MARTINS, J. S. Redação Publicitária. Teoria e Prática. São Paulo: Atlas, 1997.

MASSINI-CAGLIARI, G. "Sobre o percurso histórico da acentuação em português". in SCARPA, E.M. (Org) Estudos de prosódia. Campinas: Unicamp, 1999. . Acento e ritmo. SP: Contexto, 1992

MCLUHAN, M. Os meios de comunicação como extensões do homem. Trad. D. Pignatari. São Paulo: Cultrix, 1969.

MORAES, J.A. de. Um algoritmo para a correção/ simulação da duração dos segmentos vocálicos em português. SCARPA, E.M. (Org) Estudos de prosódia. Campinas: Unicamp, 1999. Intonation in brazilian portuguese. Cambridge: Cambridge University Press, 1988.

OGILVY, D. Confissões de um publicitário. Trad. J.B.Oliveira. Rio de Janeiro: Difel, 1976.

Revista Gol. São Paulo: fevereiro de 2007.

SIEVERT, M. Texto publicitário. Dicas não são receitas. Blumenau: Edifurb, 2001.

TOSCANI, O. A publicidade é um cadáver que nos sorri. Trad. L.C. de M. Guerra. Rio de Janeiro: Ediouro, 2003.

VESTERGAARD/SCHRODER. A linguagem da propaganda. Trad. J. A. dos Santos. São Paulo: Martins Fontes, 2000.

http://www.forumpcs.com.br/noticia.php?b=190673 